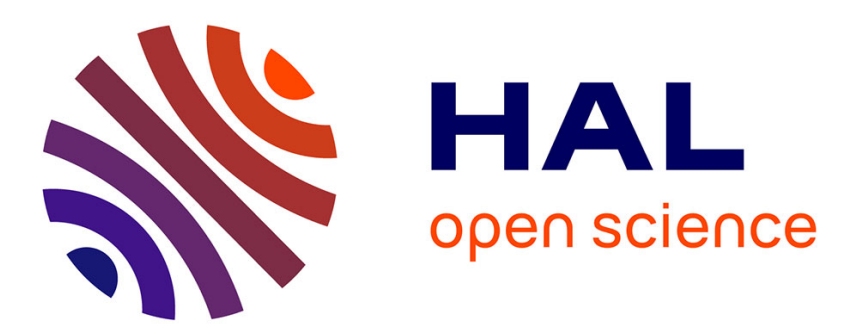

\title{
Soluble nickel inhibits HIF-prolyl-hydroxylases creating persistent hypoxic signaling in A549 cells
}

Todd Davidson, Haobin Chen, Dominic Di Toro, Gisela d'Angelo, Max Costa

\section{To cite this version:}

Todd Davidson, Haobin Chen, Dominic Di Toro, Gisela d'Angelo, Max Costa. Soluble nickel inhibits HIF-prolyl-hydroxylases creating persistent hypoxic signaling in A549 cells. Molecular Carcinogenesis, 2006, 45 (7), pp.479-489. 10.1002/mc.20176 . hal-03034114

\section{HAL Id: hal-03034114 https://hal.science/hal-03034114}

Submitted on 9 Dec 2021

HAL is a multi-disciplinary open access archive for the deposit and dissemination of scientific research documents, whether they are published or not. The documents may come from teaching and research institutions in France or abroad, or from public or private research centers.
L'archive ouverte pluridisciplinaire HAL, est destinée au dépôt et à la diffusion de documents scientifiques de niveau recherche, publiés ou non, émanant des établissements d'enseignement et de recherche français ou étrangers, des laboratoires publics ou privés. 


\title{
Soluble Nickel Inhibits HIF-Prolyl-Hydroxylases Creating Persistent Hypoxic Signaling in A549 Cells
}

\author{
Todd L. Davidson, ${ }^{1}$ Haobin Chen, ${ }^{1}$ Dominic M. Di Toro, ${ }^{2}$ Gisela D'Angelo, ${ }^{3}$ and Max Costa ${ }^{\mathbf{1}}$ * \\ ${ }^{1}$ Nelson Institute of Environmental Medicine, New York University, School of Medicine, Tuxedo, New York \\ ${ }^{2}$ Department of Civil and Environmental Engineering, University of Delaware, Newark, Delaware \\ ${ }^{3}$ Neurobiologie Vasculaire, INSERM U615, Universite de Nice Sophia Antipolis, Parc Valrose, France
}

Soluble nickel compounds are carcinogenic to humans although the mechanism by which they cause cancer remains unclear. One major consequence of exposure to nickel is the stabilization of hypoxia inducible factor- $1 \alpha(\mathrm{HIF}-1 \alpha)$, a protein known to be overexpressed in a variety of cancers. In this study, we report a persistent stabilization of HIF-1 $\alpha$ by nickel chloride up to $72 \mathrm{~h}$ after the removal of nickel from the culture media. In addition, we show that the HIFprolyl hydroxylases (PHD's) are inhibited when cells are exposed to nickel and that they remain repressed for up to $72 \mathrm{~h}$ after nickel is removed. We then show that nickel can inhibit purified HIF-PHD's 2 in vitro, through direct interference with the enzyme. Through theoretical calculations, we also demonstrate that nickel may be able to replace the iron in the active site of this enzyme, providing a plausible mechanism for the persistent inhibition of HIF-PHD's by nickel. The data presented suggest that nickel can interfere with HIF-PHD directly and does not inhibit the enzyme by simply depleting cellular factors, such as iron or ascorbic acid. Understanding the mechanisms by which nickel can inhibit HIFPHD's and stabilize HIF-1 $\alpha$ may be important in the treatment of cancer and ischemic diseases. (๑) 2006 Wiley-Liss, Inc.

Key words: iron; von Hippel Lindau; hypoxia inducible factor; metals

\section{INTRODUCTION}

Hypoxia inducible factor-1 (HIF-1) is a heterodimeric transcription factor that plays an important role in the cellular response to low oxygen conditions. It is composed of a HIF- $1 \alpha$ subunit and a HIF- $1 \beta$ subunit, both of which are members of the basic helix-loop-helix (bHLH)-containing Per-ARNT-SIM (PAS) domain family of transcription factors [1]. The HIF- $\beta$ subunit is also known as the aryl hydrocarbon receptor nuclear translocator (ARNT). Exposure to hypoxia or hypoxia-mimicking conditions (iron depletion, cobalt, nickel, 2-oxoglutarate analogs) results in the stabilization of the HIF- $1 \alpha$ subunit and the subsequent dimerization of HIF- $1 \alpha$ and HIF-1 $\beta$ / ARNT. The HIF-1 dimer can act on a large number of transcriptional targets by binding to hypoxiaresponsive elements (HRE) in the promoters of target genes [2-5]. These target genes are important for adaptation and survival under hypoxic conditions and are involved in a wide variety of processes including angiogenesis, erythropoiesis, iron transport, glycolysis, cell survival/apoptosis, and metastasis [6-8].

It is known that HIF- $1 \alpha$ is activated and stabilized in a number of cancers, including breast, brain, lung, prostate, head, and neck [9]. During cancer development, solid tumors often exhibit areas of low oxygen availability, which results in the stabilization of HIF- $\alpha$ [10]. This activation of HIF-1 leads to both angiogenesis and a switch to anaerobic metabolism, which promotes overall cell survival. The overexpression of HIF-1 and its downstream target genes has been associated with increased glycolysis, angiogenesis, metastasis, and overall tumor malignancy $[6,7,11]$. Although some studies have associated HIF1 with increased apoptosis and cell death, most studies have linked it to negative outcomes, such as increased tumor growth and metastasis [12]. Additionally, it has also been shown that disrupting HIFdependent transcription leads to an attenuation of tumor growth in nude mice [13]. Overall, HIF-1 is an important mediator of carcinogenesis progression.

In order to understand what causes the activation of HIF-1, it is important to study its regulation. The regulation of HIF-1 has become a major topic of study in recent years. The HIF- $\alpha$ and HIF-1 $\beta$ subunits are regulated in different manners. While HIF-1 $\beta$ is constitutively expressed, HIF- $\alpha$ is regulated by a variety of mechanisms, including cell signaling and

\footnotetext{
Abbreviations: HIF- $1 \alpha$, hypoxia inducible factor- $1 \alpha$; ARNT, aryl hydrocarbon receptor nuclear translocator; ODDD, oxygen-dependent degradation domain; PHD's, HIF-prolyl hydroxylases; VHL, von Hippel Lindau; DFO, deferroxamine; DMOG, dimethyloxalylglycine.

*Correspondence to: Department of Environmental Medicine, New York University School of Medicine, 57 Old Forge Rd., Tuxedo, NY 10987

Received 6 July 2005; Revised 14 November 2005; Accepted 21 November 2005

DOI 10.1002/mc.20176
} 
numerous posttranslational modifications. In addition, there are three known related forms of HIF- $\alpha$ (HIF- $1 \alpha$, HIF- $2 \alpha$, and HIF- $3 \alpha$ ) that have differences in their regulation. The regulation of HIF- $1 \alpha$ and HIF- $2 \alpha$ has been more extensively studied than that of HIF$3 \alpha$. The remainder of this report will only consider HIF- $1 \alpha$. Under normoxic conditions, HIF- $1 \alpha$ is hydroxylated at Pro 402 or Pro 564 (in the oxygendependent degradation domain (ODDD)) by the HIF-prolyl hydroxylases (PHD's1-3; also referred to as HPH1-3 and EGLN1-3) [14,15]. Following these specific proline hydroxylations, HIF-1 $[14,15]$ is then ubiquitinylated by a ubiquitin ligase complex containing the von Hippel Lindau (VHL) tumor suppressor protein, which binds tightly and specifically to hydroxylated Pro 402 and 564 in HIF-1 $\alpha$. The ubiquitinylated HIF- $1 \alpha$ is then targeted for rapid proteasome-dependent degradation. Under hypoxic or conditions mimicking this state, the PHD enzymes are inactive, and there is an absence of hydroxylation of the ODDD domain resulting in a loss of the degradation of HIF- $1 \alpha$. This leads to a stabilization of HIF- $1 \alpha$ protein. Although many other processes (acetylation, phosphorylation, and cell signaling) are involved in controlling HIF- $\alpha$, the PHD enzymes are primary regulators of HIF- $1 \alpha$ stability and may act as cellular oxygen sensors [9].

The PHD's are members of the 2-oxoglutaratedependent dioxygenase family of enzymes [16]. In addition to 2-oxoglutarate, these enzymes require $\mathrm{Fe}(\mathrm{II})$, oxygen, and ascorbic acid for activity. Interference with any of the cofactors/components of the enzyme can alter activity. Hypoxia $\left(1 \% \mathrm{O}_{2}\right)$, deferroxamine (DFO, an iron chelator), dimethyloxalylglycine (DMOG, a competitive inhibitor of 2oxoglutarate), and several divalent metals all have been shown to decrease the activity of PHD's, thereby stabilizing HIF- $1 \alpha$. The iron in the active site of these enzymes is coordinated by a 2-His-1carboxylate facial triad motif [16]. It has been suggested that divalent metals may be able to compete with or replace iron in the PHD enzymes [14].

This study focuses on the effects of soluble nickel on HIF- $1 \alpha$ and the PHD enzymes. Nickel compounds have been shown to be carcinogenic in vitro, in animal models, as well as, in epidemiological studies [17-25]. Exposures of cells to minimally toxic concentrations of $\mathrm{NiCl}_{2}(0.5-1.0 \mathrm{mM})$ were shown to be comparable to occupational exposures and high-environmental exposures of nickel compounds $[26,27]$. A major response of cells to nickel exposure is the stabilization of HIF- $1 \alpha$ and the activation of genes regulated by this transcription factor, many of which are involved with cancer progression. Using mouse fibroblasts, we have previously shown that nickel could only transform cells in the presence of HIF- $1 \alpha$, whereas in HIF- $1 \alpha$ knockouts, no growth in soft agar was observed [28]. The exact mechanism by which nickel activates HIF is unclear, though several possibilities exist. It has been reported that nickel can activate various signaling pathways such as PI-3 kinase, which may be involved in nickels' ability to stabilize HIF-1 $\alpha$ [29]. We have previously shown that nickel can interfere with iron metabolism and iron-dependent enzymes, such as aconitase, so it is reasonable to assume that nickel may also interfere with PHD enzymes [26]. In addition, another group has reported that nickel can interfere with the metabolism of ascorbate, an important molecule needed for HIF-PHD's to function properly $[26,30]$. Another hypothesis suggests that divalent metals like nickel and cobalt may bind directly to the ironbinding site in HIF-PHD, thus inactivating the enzyme. Here we investigate the effect of nickel on the activity of HIF-PHD. We show that nickel decreases HIF-PHD activity in a dose- and timedependent manner, which correlates with the stabilization of HIF- $1 \alpha$. In addition, we show that nickel inhibits PHD2 in vitro, thus providing evidence that nickel can directly inactivate PHD enzyme. Based on these results, we hypothesize that nickel can directly inhibit PHD by persistently binding to the ironbinding site in the enzyme.

\section{MATERIALS AND METHODS}

\section{Cell Culture}

Human lung A549 carcinoma cells were grown in F-12K medium (Gibco BRL, Grand Island, NY). Media was supplemented with $10 \%$ fetal bovine serum and $1 \%$ penicillin-streptomycin. Exposures were done in complete medium. In recovery experiments, cells were treated with either nickel or DFO for $24 \mathrm{~h}$, the media was then removed, cells were washed three times, and fresh culture medium was added to the dishes. Cells were allowed to recover from their exposure for a 6-, 24-, 48-, or 72-h time interval.

\section{Western Blots}

A549 cells were grown in $60 \mathrm{~mm}$ dishes to $80 \%$ confluency. Following the experimental exposure regime, the media was removed, cells were washed twice with cold PBS, and $150 \mu \mathrm{L}$ of lysis buffer $(1 \%$ SDS, $1.0 \mathrm{mM}$ sodium ortho-vanadate, and $10 \mathrm{mM}$ Tris, $\mathrm{pH}$ 7.4) at boiling temperatures was added to the dish. The lysate was then collected, transferred to an Eppendorf tube, and boiled for $5 \mathrm{~min}$. Samples were then subjected to sonication with 10 pulses ( $1 \mathrm{~s}$ each, Branson Sonifier 450) and then centrifuged at $14000 \mathrm{~g}$ for $15 \mathrm{~min}$. The supernatant was collected and used for Western blotting after the protein concentration was determined. Forty micrograms of protein was electrophoresed in a $7.5 \%$ SDS-PAGE gel and transferred to a PVDF membrane at $225 \mathrm{~mA}$ for $2 \mathrm{~h}$. Immunoblotting was performed with 1:500 diluted HIF- $1 \alpha$ primary antibody (BD Biosciences, San Jose, CA) and 1:2000 diluted secondary mouse 
antibody. Detection was accomplished by chemical florescence with an ECL Western blotting protocol (Amersham, Piscataway, NJ).

VHL Assay

The VHL assay and the preparation of GST-ODD, and ${ }^{35}$ S-labeled VHL protein has been described previously [31]. In brief, glutathione-purified GSTODD (nucleotides 1616-1837 of HIF-1 $\alpha$ ) was combined with cell extracts isolated from treated or untreated samples in a reaction buffer containing $40 \mathrm{mM}$ Tris $\mathrm{pH} 7.5,0.5 \mathrm{mM}$ DTT, $50 \mu \mathrm{M}$ ferrous sulfate, $1 \mathrm{mM}$ ascorbate, $2 \mathrm{mg} / \mathrm{mL}$ of bovine serum albumin, $0.4 \mathrm{mg} / \mathrm{mL}$ of catalase, and $0.3 \mathrm{mM} \mathrm{2-}$ oxoglutarate at $37^{\circ}$ for $30 \mathrm{~min}$. The reaction products were then incubated with $50000 \mathrm{dpm}$ of ${ }^{35} \mathrm{~S}$-labeled VHL protein (synthesized from pcDNA3.1/V5-HisvHL and the TNT-coupled reticulocyte lysate system (Promega, Madison, WI) in binding buffer $(50 \mathrm{mM}$ Tris pH 7.5, $120 \mathrm{mM} \mathrm{NaCl}, 0.5 \% \mathrm{NP} 40$ ) for $2 \mathrm{~h}$ at $4^{\circ} \mathrm{C}$. Beads were then washed three times in NTEN buffer (20 mM Tris pH 7.5, $100 \mathrm{mM} \mathrm{NaCl}, 0.5 \% \mathrm{NP} 40$, and $1 \mathrm{mM}$ EDTA). After washing, the remaining proteins were eluted from the beads by boiling in SDS running buffer for $5 \mathrm{~min}$. The eluent was run on a $15 \%$ gel and ${ }^{35}$ S-labeled VHL was visualized with ENLIGHTNING solution (Perkin Elmer, Wellesley, MA).

\section{IRP-1 Electrophoretic Mobility Shift Assay}

The assay was performed as previously described [32]. Briefly, cells were exposed to nickel for $24 \mathrm{~h}$ and allowed to recover. At selected time intervals, cells were collected and lysed for 20 min on ice with lysis buffer (10 mM HEPES, pH 7.5, $3 \mathrm{mM} \mathrm{MgCl}_{2}, 40 \mathrm{mM}$ $\mathrm{KCl}, 5 \%$ glycerol, $0.3 \% \mathrm{NP}-40$, one tablet Roche complete protease inhibitor cocktail, EDTA free). Lysate was centrifuged at $14000 \mathrm{~g}$ for $20 \mathrm{~min}$ at $4^{\circ} \mathrm{C}$. The supernatant was then transferred to a clean tube and quantified. Samples were diluted to $1 \mu \mathrm{g} / \mu \mathrm{L}$ with lysis buffer. Two micrograms of protein extract was incubated with ${ }^{32} \mathrm{P}$-labeled RNA transcript (iron response element probe) for $20 \mathrm{~min}$ at room temperature. One unit of RNAse (Roche, Indianapolis, IN) was then added to the reaction for $10 \mathrm{~min}$ to digest any unprotected RNA. Two microliters of heparin $(50 \mathrm{mg} / \mathrm{mL})$ was added for an additional 10 min to eliminate nonspecific binding. The RNAprotein complex was electrophoresed on a $5 \%$ nondenaturing polyacrylamide gel. The gel was then dried and radioactivity was detected with a Storm 860 Phosphorimaging scanner (Molecular Dynamics, Sunnyvale, CA).

In Vitro HIF-Prolyl Hydroxylase Assay

The nonradioactive in vitro HIF-PHD assay was performed as previously described [33]. Briefly, HIF peptide (Biotinyl-DLDLEMLAPYIPMDDDFQL) was immobilized on 96-well NeutrAvidin high-binding capacity plates (Pierce, Rockford, IL). Purified prolyl hydroxylase enzyme (HIF-PHD2) was added to the peptide substrate in $20 \mathrm{mM}$ Tris, $\mathrm{pH} 7.5,5 \mathrm{mM} \mathrm{KCL}$, $1.5 \mathrm{mM} \mathrm{MgCl}_{2}, 100 \mu \mathrm{M}$ 2-oxoglutarate, 5-50 $\mu \mathrm{M}$ ferrous sulfate, and $2 \mathrm{mM}$ ascorbate in a final volume of $100 \mu \mathrm{L}$ at room temperature for $30 \mathrm{~min}$. Hydroxylated HIF-peptide was then detected by adding $2.2 \mu \mathrm{g} 6$ His-Trx-VBC (VHL protein-elongin Belongin $\mathrm{C}$ complex) in $80 \mu \mathrm{L}$ of binding buffer (50 mM Tris, pH 7.5, $120 \mathrm{mM} \mathrm{NaCl}$ ) to each well. Binding of VBC to hydroxylated HIF- $1 \alpha$ peptide was allowed to occur for $15 \mathrm{~min}$ at room temperature. An anti-thioredoxin antibody (1:4000) was then added to the binding mixture for $30 \mathrm{~min}$ (T 0803, Sigma, St. Louis, MO). Following this, $10 \mu \mathrm{L}$ of anti-mouse IgG peroxidase conjugate (1:200) was added and the mixture incubated for an additional $30 \mathrm{~min}$ (A 0168, Sigma). The wells were then washed three times with wash buffer and incubated with a TMB substrate kit for $15 \mathrm{~min}$ at room temperature (Pierce). The reaction was stopped by adding $100 \mu \mathrm{L}$ of $\mathrm{H}_{2} \mathrm{SO}_{4}$ and bound VBC was calculated by measuring the $\mathrm{OD}$ at $450 \mathrm{~nm}$ with a Tecan Spectra plate reader.

\section{HIF-Prolyl Hydroxylase Modeling}

In order to simplify the analysis of the Fe-binding site of HIF-PHD's and other dioxygenases, appropriate smaller molecules were substituted for the large amino acid groups, viz. histidine was modeled as imidazole (imid). The binding constants of various metals to either one or two histidines were calculated from National Institute of Standards and Technology (NIST) data according to the following reaction [34], where $n=1$ or 2 .

$$
\mathrm{M}\left(\mathrm{H}_{2} \mathrm{O}\right)_{6}^{2+}+\mathrm{imid}_{n} \leftrightarrow \mathrm{M}\left(\mathrm{H}_{2} \mathrm{O}\right)_{6-n}(\text { imid })_{\mathrm{n}}^{2+}+n \mathrm{H}_{2} \mathrm{O}
$$

The strength of binding is quantified using the log of the equilibrium constants.

\section{RESULTS}

Nickel Stabilizes HIF-1 $\alpha$ Protein in a Dose- and Time-dependent Manner

Since various divalent metals have been shown to affect the protein stability of HIF- $1 \alpha$, the effect of nickel chloride on HIF- $1 \alpha$ in A549 cells was assessed by Western blot. Exposure to nickel chloride for $5 \mathrm{~h}$ substantially increased the expression of HIF- $1 \alpha$ in a dose- and time-dependent manner (Figure $1 \mathrm{~A}$ and $\mathrm{B}$ ). Exposure time intervals between 6 and $72 \mathrm{~h}$ led to continued expression of HIF- $1 \alpha$, with no major decrease of protein levels over time. The effect of nickel chloride on HIF- $1 \alpha$ expression in A549 cells appeared to be specific, because other metallic compounds, such as potassium chromate and sodium vanadate, at doses that have been shown to result in similar toxicities as was caused by $1 \mathrm{mM}$ nickel chloride, were unable to induce HIF- $1 \alpha$ after a 6-h exposure (Figure 1C). 
A

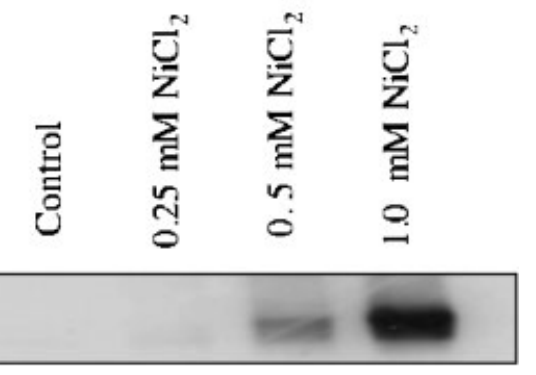

$\alpha$-Tubulin

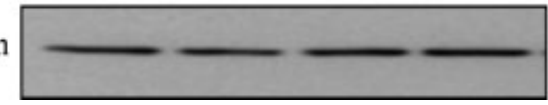

B

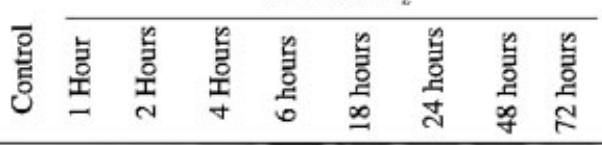

HIF-10

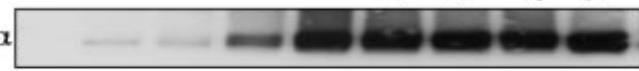

$\alpha$-Tubulin

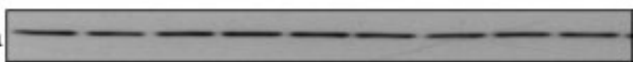

\section{C}

HIF-1 $\alpha$

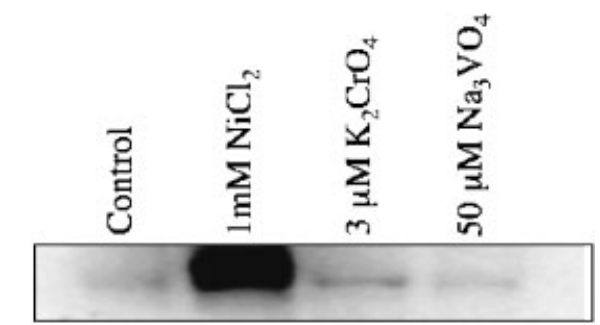

Tubulin

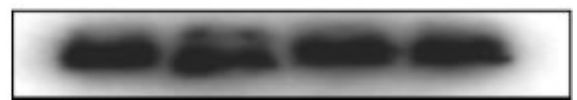

Figure 1. Hypoxia Inducible Factor-1 $\alpha$ (HIF-1 $\alpha)$ protein induction following treatment with soluble nickel chloride. A549 cells were treated with (A) increasing concentrations of $\mathrm{NiCl}_{2}$ for $6 \mathrm{~h}(0-1.0 \mathrm{mM}$ $\mathrm{NiCl}_{2}$ ) (B) $1 \mathrm{mM} \mathrm{NiCl}$ for the times indicated, (C) $1 \mathrm{mM} \mathrm{NiCl}_{2} 3 \mu \mathrm{M}$ $\mathrm{K}_{2} \mathrm{CrO}_{4}$, and $50 \mu \mathrm{M} \mathrm{Na}_{3} \mathrm{VO}_{4}$ for $6 \mathrm{~h}$. Forty micrograms of protein was subjected to Western blot analysis and primary antibodies were used to detect the presence of HIF-1 $\alpha$. Primary antibodies against $\alpha$-tubulin were also used to confirm equal loading. Western blots shown are representative of three independent experiments.

Nickel Chloride Decreases Binding of VHL to the ODD Domain of HIF- $1 \alpha$, but Not Potassium Chromate, Sodium Vanadate, nor Deferroxamine

We have previously shown that nickel chloride can decrease the binding of VHL to the ODDD domain of HIF- $1 \alpha$ in a dose-dependent manner [35]. Here we show that exposure of cells to $1 \mathrm{mM}$ nickel chloride caused a loss of VHL binding activity over time (Figure 2A). This decrease in binding with time correlated with an increased expression of HIF- $1 \alpha$.
A

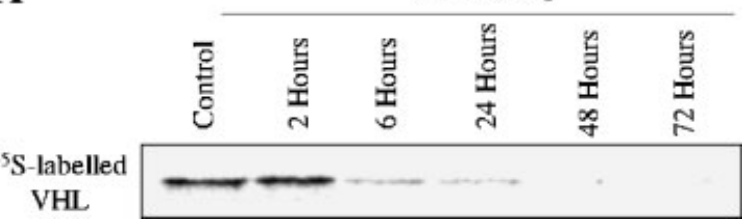

B
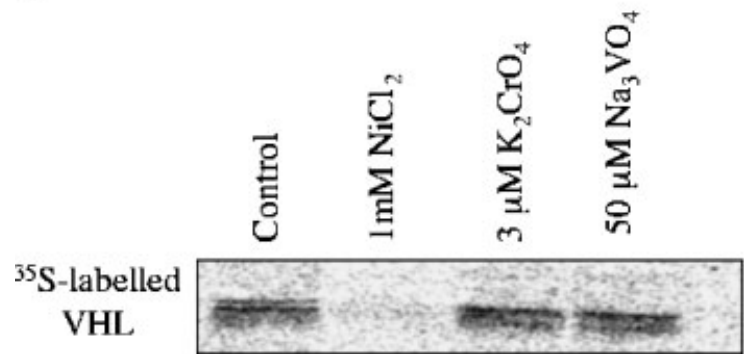

C
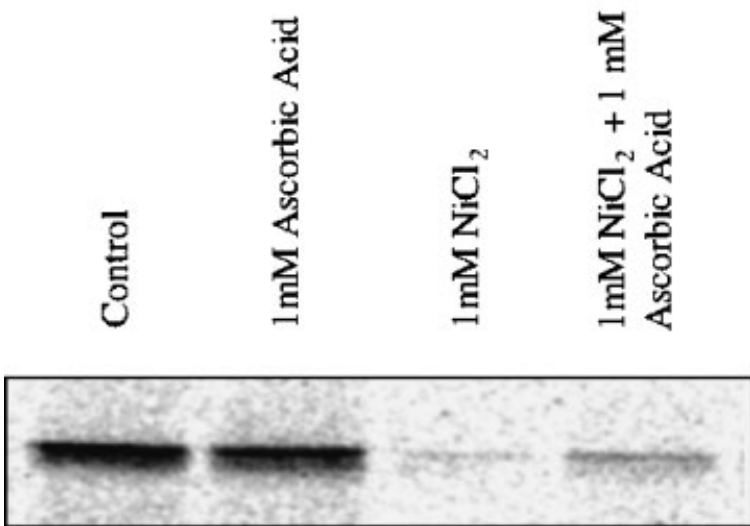

D

${ }^{35}$ S-labelled VH

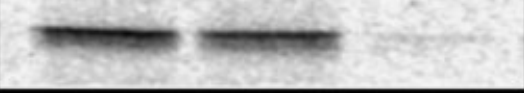

Figure 2. Nickel decreases the binding of von Hippel Lindau (VHL) protein to the oxygen-dependent degradation domain (ODDD) of HIF-1 $\alpha$. A549 cells were treated with (A) $1 \mathrm{mM} \mathrm{NiCl}_{2}$ for the times indicated, (B) $1 \mathrm{mM} \mathrm{NiCl}_{2}, 3 \mu \mathrm{M} \mathrm{K}_{2} \mathrm{CrO}_{4}$, and $50 \mu \mathrm{M} \mathrm{Na}_{3} \mathrm{VO}_{4}$ for $6 \mathrm{~h}$ (C) $1 \mathrm{mM} \mathrm{NiCl}, 1 \mathrm{mM}$ ascorbic acid, or $1 \mathrm{mM} \mathrm{NiCl} 2$, and $1 \mathrm{mM}$ ascorbic acid for $6 \mathrm{~h}$, (D) $200 \mu \mathrm{M}$ DFO, $1 \mathrm{mM}$, or $1 \mathrm{mM} \mathrm{NiCl}$ for $6 \mathrm{~h}$. Extracts from treated cells were used for in vitro hydroxylation of glutathione purified GST-ODD. ${ }^{35}$ S-labeled VHL was allowed to bind any hydroxylated ODDD. Bound VHL was eluted and run in a 15\% gel and visualized with ENLIGHTNING solution. Experiments were repeated three times and representative gels were chosen for publication. 
Additionally, we showed that the effect of nickel on VHL binding activity was specific because $3 \mu \mathrm{M}$ potassium chromate and $50 \mu \mathrm{M}$ sodium vanadate did not affect VHL binding activity after a 6-h exposure (Figure 2B). The cotreatment of cells with nickel and ascorbic acid was only partially able to reverse the decrease in binding activity caused by nickel alone (Figure 2C). Surprisingly, we also observed that a 6-h exposure to the iron chelator DFO was unable to decrease VHL binding activity (Figure 2D). This is most likely because of the required exogenous addition of iron to measure enzyme activity.
HIF- $1 \alpha$ Remained Stabilized and PHD's Remained Inhibited Following Removal of Nickel Chloride From the Culture Media

Since it has been suggested that nickel may inactivate HIF-PHD's by a direct binding mechanism, we studied the expression of HIF- $1 \alpha$ after nickel was removed from the culture media. Cells were exposed to either $1 \mathrm{mM} \mathrm{NiCl}_{2}, 200 \mu \mathrm{M} \mathrm{DFO}$, or $1 \mathrm{mM}$ DMOG for $24 \mathrm{~h}$ and allowed to recover for a specified time interval. After the removal of nickel, HIF- $1 \alpha$ levels decreased but remained elevated well above control levels (Figure 3A). In contrast, after removal

$\mathbf{A}$
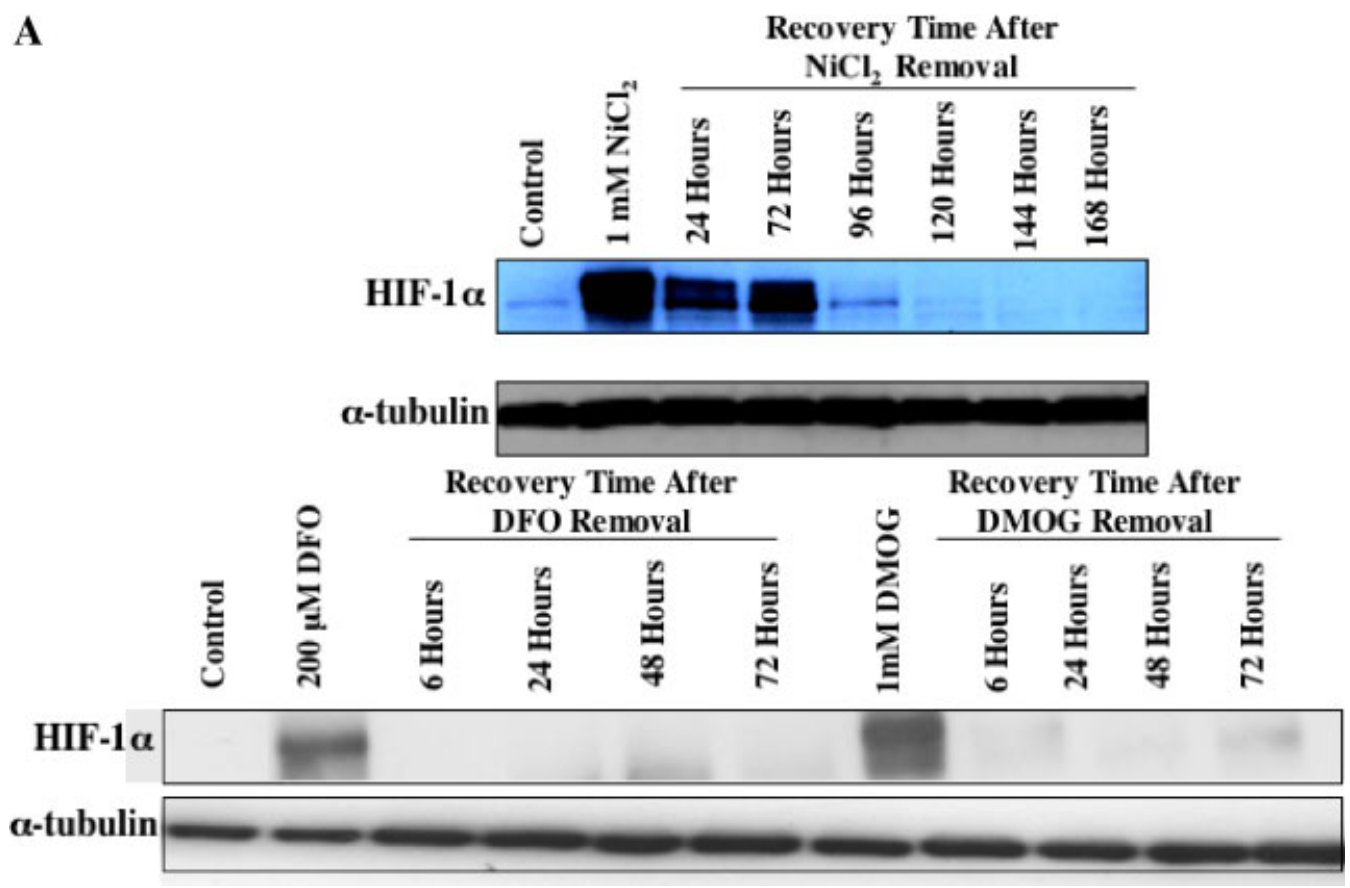

B

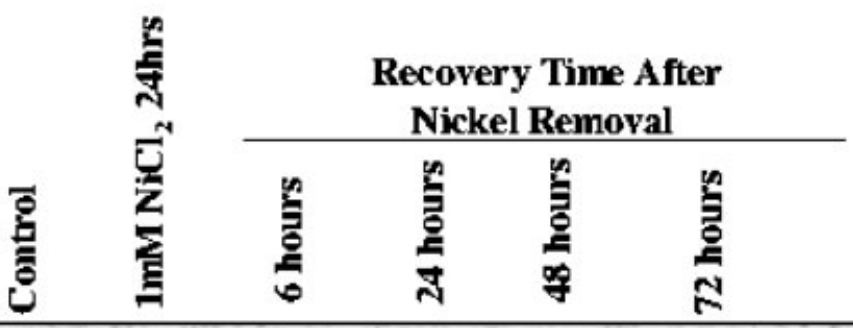

${ }^{35}$ S-labelled VHL

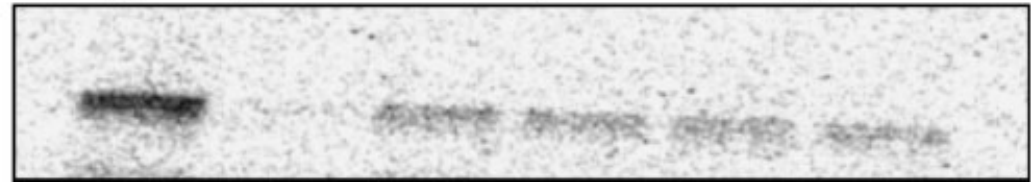

Figure 3. Persistent hypoxic signaling after soluble nickel treatment. (A) Western blot of HIF-1 $\alpha$ during the recovery of cells exposed to $1 \mathrm{mM} \mathrm{NiCl}, 200 \mu \mathrm{M}$ DFO, or $1 \mathrm{mM}$ DMOG for $24 \mathrm{~h}$. Forty micrograms of protein was subjected to Western blot analysis and primary antibodies were used to detect the presence of HIF-1 $\alpha$. Primary antibodies against $\alpha$-tubulin were also used to confirm equal loading. (B) Binding of $\mathrm{VHL}$ to the ODDD of HIF- $1 \alpha$ during the recovery $\left(6-72 \mathrm{~h}\right.$ ) of cells exposed to $1 \mathrm{mM} \mathrm{NiCl}_{2}$ for $24 \mathrm{~h}$. Extracts from treated cells were used for in vitro hydroxylation of glutathione purified GST-ODD. ${ }^{35}$ S-labeled VHL was allowed to bind any hydroxylated ODDD. Bound VHL was eluted and run in a $15 \%$ gel and visualized with ENLIGHTNING solution. [Color figure can be viewed in the online issue, which is available at www.interscience. wiley.com.] 
of DFO or DMOG, HIF- $1 \alpha$ levels dropped to basal levels after only a few hours (Figure 3A). These results show that nickel had a persistent effect on the stabilization of HIF- $1 \alpha$, when compared to DFO or DMOG. To further study the mechanism for this effect, VHL binding activity during the recovery of cells exposed to $\mathrm{NiCl}_{2}$ for $24 \mathrm{~h}$ was studied (Figure 3B). VHL binding recovered slightly, but after $72 \mathrm{~h}$, it still remained significantly lower than control levels. The decreased VHL binding activity and increased HIF- $1 \alpha$ protein levels during the recovery of cells exposed to $\mathrm{NiCl}_{2}$ for $24 \mathrm{~h}$ were expected and thus mutually reinforced our proposed mechanism.

IRP-1 Binding Activity Returns to Control Levels after Removal of $\mathrm{NiCl}_{2}$ From the Culture Media

To investigate the availability of iron in cells after exposure to nickel, IRP-1 binding activity was measured with an EMSA assay. A sizable increase in IRP-1 binding activity following a 24-h exposure to $\mathrm{NiCl}_{2}$ was found, suggesting a loss of bioavailable iron from cells. During a recovery period, IRP-1 binding activity begins to decrease towards basal levels within 8-24 h (Figure 4), demonstrating indirectly that the cellular bioavailable iron pools were easily replenished when exposure to nickel ceased.

Nickel Inhibits Purified HIF-prolyl Hydroxylase (PHD2) In Vitro

A nonradioactive assay to measure the activity of purified HIF-PHD has been previously developed [33]. To study whether $\mathrm{NiCl}_{2}$ may directly affect the PHD2 enzyme, we analyzed the activity of the purified enzyme with iron in the absence or presence of varying levels of $\mathrm{NiCl}_{2}$. Here we show that the enzyme activity of PHD2 was activated by exogenous addition of $\mathrm{FeSO}_{4}$ with an effective concentration $50\left(\mathrm{EC}_{50}\right)$ of $6.6 \mu \mathrm{M}$ (Figure $5 \mathrm{~A}$ ). This result indicates that the purified enzyme does not retain $\mathrm{Fe}^{2+}$, and that $\mathrm{Fe}^{2+}$ loss and replenishment can easily be

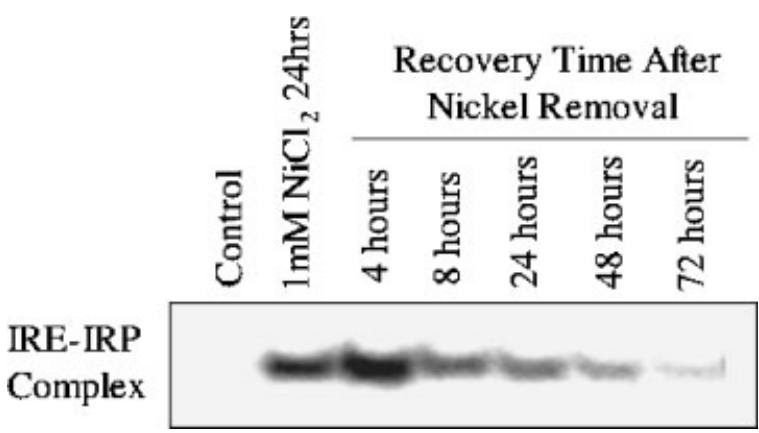

Figure 4. IRP binding activity after soluble nickel treatment. IRP binding assay during the recovery (4-72 h) of cells exposed to $1 \mathrm{mM}$ $\mathrm{NiCl}_{2}$ for $24 \mathrm{~h}$. Two micrograms of cytosolic extract was subjected to EMSA as described in the Materials and Methods section. All EMSA as described in the Materials and Methods section. All
experiments were repeated in triplicate and representative experiments were chosen for publication.
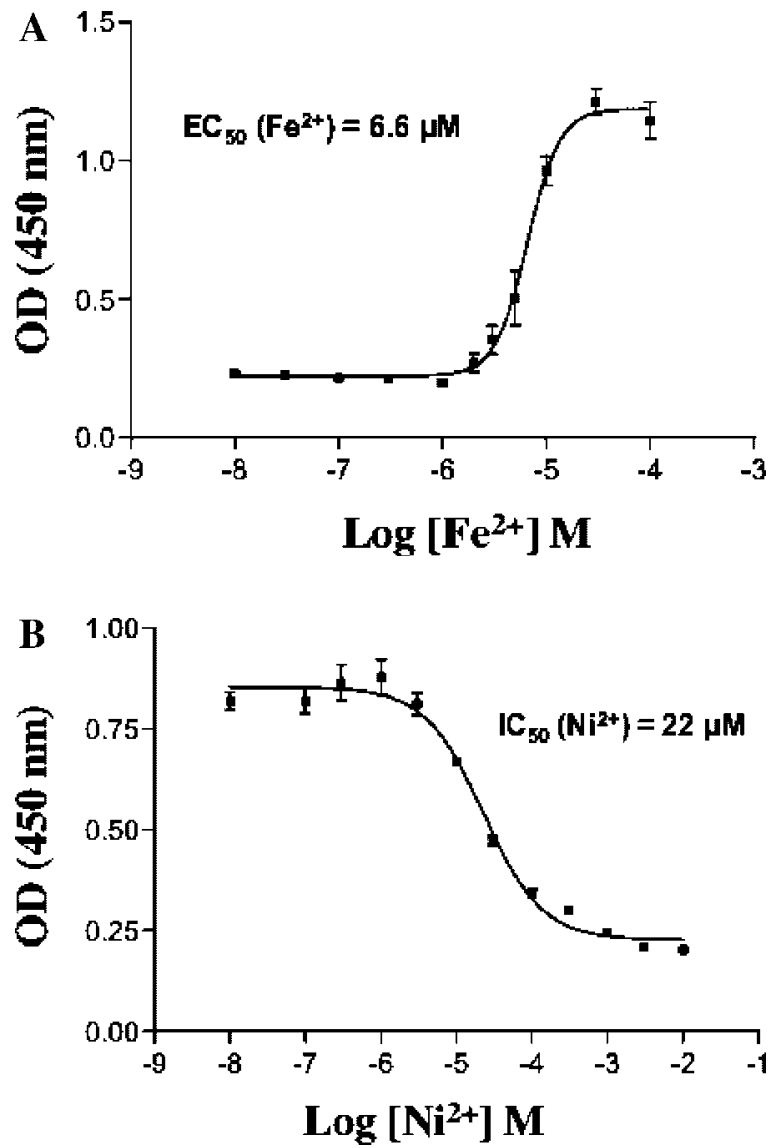

Figure 5. Iron activates and nickel inhibits purified HIF-Prolyl Hydroxylase 2 (PHD2) enzyme in vitro. The activity of purified PHD2 was determined for enzyme treated with (A) increasing concentrations of $\mathrm{FeSO}_{4},(\mathrm{~B})$ increasing concentrations of $\mathrm{NiCl}_{2}$ in the presence of iron. The activity was measured in the presence of ascorbate, 2-oxoglutarate, and oxygen by the binding of a purified $\mathrm{pVHL}$-elonginB-elonginC complex to a peptide resembling the ODDD of HIF- $1 \alpha$ as described in the Materials and Methods section. MBP-PHD2 was expressed and isolated from bacteria. Experiments were performed in triplicate and are shown as mean value \pm standard deviations.

accomplished in vitro, in contrast to many proteins and enzymes that retain $\mathrm{Fe}^{2+}$ in a tightly bound configuration. Using an iron concentration that yielded maximal activity, we studied the ability of $\mathrm{NiCl}_{2}$ to inhibit PHD2 in vitro. $\mathrm{NiCl}_{2}$ was able to inhibit the enzyme in a dose-dependent manner with an inhibiting concentration $50\left(\mathrm{IC}_{50}\right)$ of $22 \mu \mathrm{M}$ (Figure 5B), illustrating that $\mathrm{NiCl}_{2}$ directly affects PHD2.

Simplified Modeling of PHD Enzymes Indicates that Nickel Is Able to Replace Iron

An analysis of the equilibrium binding constants to imid reveal that $\mathrm{Ni}^{2+}$, as well as $\mathrm{Co}^{2+}, \mathrm{Cd}^{2+}, \mathrm{Zn}^{2+}$, and $\mathrm{Cu}^{2+}$ all have significantly higher equilibrium constants than $\mathrm{Fe}^{2+}$ for the binding to one or two imid molecules (Figure 6). Since the $\mathrm{Fe}^{2+}$ in HIF-PHD is bound to the imid functional groups of the two histidine molecules, we used the imid ligand to 


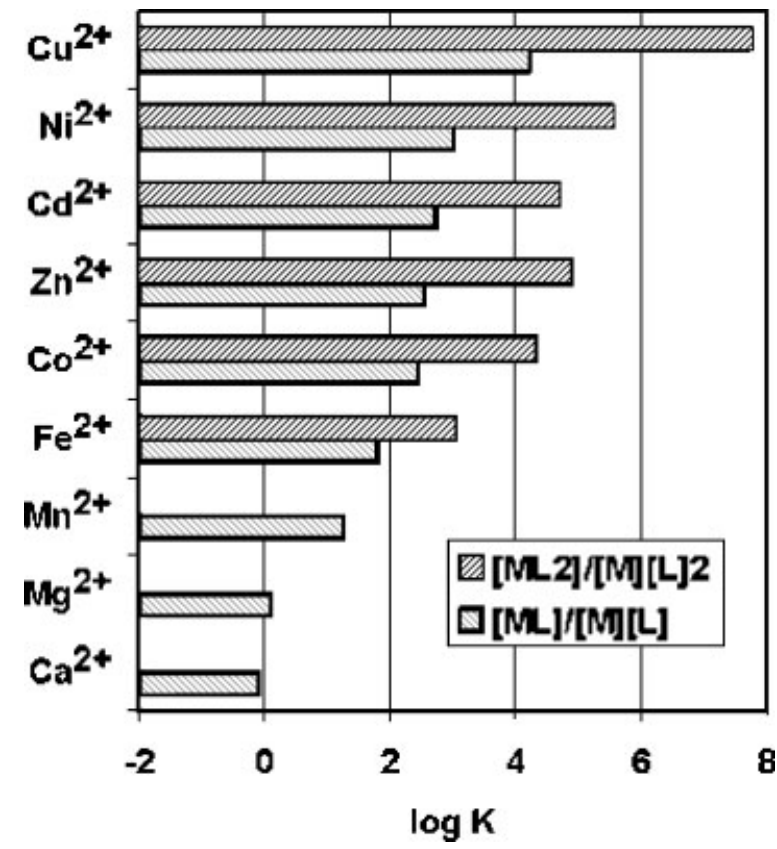

Figure 6. Binding constants for divalent metals to either one or two imidazole (imid) ligands. imid is commonly used to model histidines, which are essential iron binding molecules in the PHD enzymes. Binding constants are expressed as log values and were calculated according to the following reaction. $\mathrm{M}$, divalent metal ion; $\mathrm{L}$, Ligand. $\mathrm{M}\left(\mathrm{H}_{2} \mathrm{O}\right)_{6}^{2+}+$ imid $_{n} \leftrightarrow \mathrm{M}\left(\mathrm{H}_{2} \mathrm{O}\right)_{6-n}(\mathrm{imid})_{n}^{2+}+n \mathrm{H}_{2} \mathrm{O}$

model the binding and exchange of metal to HIFPHD. This analysis suggests these molecules should be able to replace $\mathrm{Fe}^{2+}$ that is bound by the two histidines of HIF-PHD. The binding strength of $\mathrm{Ni}^{2+}$ coordination to two imid molecules is approximately three orders of magnitude greater than for $\mathrm{Fe}^{2+}$ to bind the same two molecules. $\mathrm{Cu}^{2+}$ showed the strongest binding ability (over 4.5 orders of magnitude greater than $\left.\mathrm{Fe}^{2+}\right) . \mathrm{Mn}^{2+}, \mathrm{Mg}^{2+}$, and $\mathrm{Ca}^{2+}$ showed a weaker affinity for imid molecules than iron.

\section{DISCUSSION}

Based on the available data, the International Agency for Research on Cancer (IARC) has classified nickel compounds, other than metallic nickel and certain alloys, as Group I human carcinogens [22]. Although insoluble nickel compounds are generally described as more carcinogenic, recent epidemiological studies have identified soluble nickel compounds as being carcinogenic or acting as enhancers for other carcinogenic compounds $[20,21,36]$. Various hypotheses on the mechanisms of nickelinduced carcinogenesis exist, including interference with iron homeostasis/iron-dependent enzymes, epigenetic changes, cell signaling, oxidative stress, and interference with repair enzymes [37-40]. It is possible that only one mechanism is important but, more likely, a combination of the proposed mechanisms may lead to cell transformation or the promo- tion of tumorigenesis. Here we suggest a mechanism by which soluble nickel compounds decrease the activity of PHD enzymes, thereby persistently preventing the degradation of HIF- $1 \alpha$ protein. This persistent hypoxic signaling results in the induction of genes such as vascular endothelial growth factor (VEGF), glycolytic enzymes, and glucose transporters, which will allow cancer cells to proliferate under low-oxygen conditions.

HIF- $1 \alpha$, which is upregulated in many types of cancers, is believed to be an important driving force during carcinogenesis and angiogenesis. In fact, when a tumor reaches a critical size, regions of it become hypoxic, which leads to necrosis [10]. In order to grow larger than a few millimeters, neovascularization needs to occur and induction of HIF- $1 \alpha$ by hypoxia leads to the production of the necessary angiogenic factors and their receptors [41]. Since the induction of HIF- $1 \alpha$ and its downstream genes have been shown to be important in the carcinogenic process, several studies have targeted the HIF- $1 \alpha$ pathway as a way to inhibit tumor growth. Indeed several groups have shown that by disrupting components of the HIF- $1 \alpha$ pathway or lowering HIF- $\alpha$ levels by overexpressing PHD enzymes, tumor vascularization, and growth could be inhibited $[13,42]$. In addition, several therapeutic drugs, such as Avastin ${ }^{\mathrm{TM}}$ (Genentech), have been developed that target components of the HIF- $1 \alpha$ pathway.

We have previously reported that soluble nickel is able to stabilize HIF- $1 \alpha$ and induce HIF- $1 \alpha$-dependent genes $[43,44]$. It should be noted that in our studies nickel is used in the millimolar range (0.5$1.0 \mathrm{mM}$ ) compared to micromolar doses used for metals, like chromium and vanadate. This is because chromium and vanadate are generally more toxic than nickel in A549 cells. As a result, the effects of nickel may be strictly dose related, though this is not likely because chromium has been shown to induce HIF- $1 \alpha$ in DU145 cells in the micromolar range [45]. We have also previously demonstrated the importance of HIF-1 $\alpha$ in nickel-induced transformation [28]. Though our earlier studies showed an induction of HIF- $1 \alpha$ at earlier time points, here we demonstrate the presence of HIF- $1 \alpha$ protein maintained at high levels in the presence of soluble nickel for at least $72 \mathrm{~h}$ (the latest time point we studied). Additionally, we show that HIF- $1 \alpha$ remained elevated and PHD's remain inhibited for at least $72 \mathrm{~h}$, even after soluble nickel was removed from cells. It is worthy to note that nickel could still inhibit PHD activity $72 \mathrm{~h}$ after it was removed. Under normal conditions, it would be expected that inhibited PHD enzyme should be replaced by de novo protein synthesis. One potential explanation for the observed persistent inhibition is that nickel, even $72 \mathrm{~h}$ after removal, still remains in the cell loosely bound to intracellular ligands and is available to inhibit newly synthesized PHD enzyme. It is also possible that the enzyme has a long half-life 
and the turnover rate is relatively slow. Interestingly, it has been reported in vivo, that the collagen prolyl hydroxylase, a structurally related enzyme, has a relatively long half life of $46 \mathrm{~h}$ [46]. Since the inhibition of PHD's and the stabilization of HIF- $1 \alpha$ have been shown to be critical in the carcinogenic process, it is reasonable to believe that the prolonged induction of this protein by soluble nickel may be an important factor in nickel-induced carcinogenesis.

The mechanism by which nickel stabilizes HIF- $1 \alpha$ is unknown. It has been discovered that the stability of the HIF- $1 \alpha$ protein is controlled by the PHD enzymes, which require iron, ascorbic acid, 2oxoglutarate, and oxygen to function properly $[14,15]$. Several hypotheses have been presented on how nickel may interfere with PHD's. It has been suggested that interference with iron homeostasis, oxidation/depletion of ascorbic acid, and direct binding of the enzyme may be important factors in the ability of nickel to affect the PHD enzymes $[26,30]$.

Here, we used the VHL assay to indirectly measure PHD activity from cell extracts that were isolated from nickel treated cells. The in vitro hydroxylation performed during the VHL assay requires the addition of iron to the reaction mixture for activity. If nickel was decreasing PHD activity by solely depleting iron, then its addition during the hydroxylation reaction should counteract the cellular effect of nickel. When the VHL assay was performed on cell extracts from nickel treated cells, the binding of VHL to the ODDD was greatly diminished even though exogenous iron was added. When cells were treated with DFO and their extracts were used for the VHL assay, we observed no decrease in VHL binding activity. Since sufficient iron was added exogenously to the reaction mixture, it reversed the depletion of cellular iron caused by DFO. These data suggest that the inhibition of PHD's by exposure of cells to soluble nickel cannot be attributed to cellular depletion of iron.

Since nickel has been shown to compete with iron for entry into the cell at the divalent metal ion transporter (DMT1), we investigated the possibility that nickel may irreversibly block iron uptake into cells [26], by measuring IRP levels during a recovery period following exposure to nickel. IRP binding activity increased after $24 \mathrm{~h}$ of exposure of cells to soluble nickel, indicating a decrease in the labile iron pool. When the nickel was removed from the media, IRP binding activity remained unchanged for the first $4 \mathrm{~h}$ but by $8 \mathrm{~h}$ it decreased significantly, suggesting that iron was able to reenter the cell or that intracellular iron pools were being replenished by some other mechanism. By $72 \mathrm{~h}$ after nickel removal, IRP binding approached basal levels (Figure 4), while HIF-PHD activity and HIF protein remained significantly depressed and stabilized, respectively, under similar conditions (Figure 3A and B). Since, we have previously shown that iron uptake is inhibited by $\mathrm{NiCl}_{2}$ at the level of DMT-1, we assume that this is the major operative mechanism for depletion and restoration of cellular iron levels, and activation and restoration of IRP activity [26]. These results suggest that a permanent block of iron uptake was probably not responsible for the effect of nickel on the PHD enzymes and HIF-1 $\alpha$ stabilization.

It has been reported that ascorbic acid can reverse the stabilization of HIF- $1 \alpha$ by nickel, leading to the hypothesis that the nickel induced depletion of cellular ascorbic acid caused the inhibition of PHD's [30]. The evidence presented here supports the notion that the observed decrease in PHD activity by nickel was not solely due to depletion of ascorbic acid. In addition to iron, the in vitro hydroxylation reaction performed during the VHL assay calls for the addition of ascorbic acid. If the observed decrease in PHD activity by nickel was brought about by depletion of ascorbic acid, then adding it back during the VHL assay should have reversed the effects of nickel. In fact, when cells were treated with nickel and their extracts used for the VHL assay, PHD activity remained inhibited. This demonstrates that in vitro, nickel inhibits PHD activity, even after the addition of exogenous ascorbic acid. Although ascorbic acid was not able to reverse the inhibition of PHD's by nickel in vitro and only partially able to reverse the binding of VHL to ODD when cells were cotreated with the two compounds, it has been shown to reverse the induction of HIF- $1 \alpha$ by nickel when added to cells [30]. In addition to nickel, ascorbic acid can also reverse the induction of HIF- $1 \alpha$ in cells by DFO, insulin-like growth factor (IGF), and insulin, chemicals that do not likely deplete ascorbic acid, thus indicating another mechanism of action for ascorbic acid [47]. Ascorbic acid was also shown to reduce high basal levels of the HIF- $1 \alpha$ protein [47]. Since treating cells with ascorbic acid has been shown to increase the available iron, the ability of ascorbic acid to reverse the induction of HIF-1 $\alpha$ by nickel and DFO may be related to its ability to increase the overall availability of iron to the enzyme [48]. It may also increase the availability of iron at the active site of the enzyme by keeping iron in the $\mathrm{Fe}^{2+}$ form (uncoupled cycles lead to the formation of $\left.\mathrm{Fe}^{3+}\right)$. Furthermore, there is a very poor chemical reaction between $\mathrm{Ni}^{2+}$ and ascorbic acid in contrast to the reaction between chromate and ascorbic acid, which is the major reducer of $\mathrm{Cr}^{6+}$ to $\mathrm{Cr}^{3+}$ in the cell. Although chromate can stabilize HIF- $1 \alpha$, it does so poorly and requires toxic concentrations. Finally, oxidation of ascorbic acid with ascorbate oxidase did not affect HIF- $1 \alpha$ protein levels at 25 or $24 \mathrm{~h}$ (data not shown). Overall, ascorbic acid is an important mediator of PHD activity, although depletion of ascorbic acid by nickel alone does not 
appear to be sufficient for nickel to inhibit PHD activity.

These data argue that the pronounced effect of $\mathrm{Ni}^{2+}$ on HIF- $1 \alpha$ stabilization resides on its persistent inhibition of HIF-PHD, via its ability to displace iron from the enzyme. This hypothesis is not unreasonable because several divalent metal ions have been shown to inhibit the collagen-prolyl-4-hydroxylase competitively with respect to iron [49-52]. The collagen-prolyl-4-hydroxylase is in the same 2oxoglutarate-dependent dioxygenase family of enzymes as the PHD's and its iron is also held in place by a 2-His-1-carboxylate facial triad motif. Other iron-dependent enzymes, like pthalate dioxygenase, have also been shown to be inhibited by divalent metals that occupy the mononuclear iron site $[53,54]$. Furthermore, spectroscopic and structural studies on the active site of Isopenicillin-NSynthase (IPNS) and factor inhibiting HIF (FIH1), other 2-oxo-glutarate-dependent dioxygenases, have also shown that several divalent metals can substitute for $\mathrm{Fe}^{2+}$ [55-57]. One reason that nickel may be able to mimic iron is that they are very similar in terms of atomic structure and ionic radii [58]. Here we show that nickel can directly inhibit PHD2 in vitro, suggesting that nickel may directly bind the enzyme. Since nickel affects the isolated enzyme, without depletion of intracellular iron or ascorbic acid from a cell, the hypothesis that nickel may replace iron in the active site of the enzyme is highly plausible. In the cell however, the depletion of iron and ascorbic acid by nickel likely play a role in the ability of nickel to directly affect PHD enzymes. Our data do not rule out the possibility that nickel may bind to another site on the enzyme causing its inactivation, though this seems unlikely given the poor binding of iron to PHD and the fact that the isolated enzyme has no iron in it, but can easily be reactivated by exogenous addition of iron in the reaction. It has also been reported that cobalt could directly bind to HIF- $1 \alpha$ and prevent the binding of VHL, thereby stabilizing HIF- $1 \alpha$ [59]. To exclude this possibility, we treated HIF- $1 \alpha$ peptide with nickel and used it for the VHL binding assay. We observed no changes in VHL binding compared to the control sample (data not shown). To further support the hypothesis that nickel could replace iron in the active site of PHD's, we examined the ability of several divalent metals to replace $\mathrm{Fe}^{2+}$ bound to two imids (commonly used to model histidines). We found that copper, nickel, cadmium, zinc, and cobalt all had greater binding affinities to two imids than $\mathrm{Fe}^{2+}$. We are in the process of conducting a more complex molecular modeling of the PHD active site. In support of these calculations, most of these metals have been shown to inhibit PHD's in vitro and in cells $[33,60]$. It is also of interest to note that addition of excess iron did not reverse the in vitro inhibition of PHD's by nickel or copper [60]. This may be because nickel and copper bind to the two histidines with approximately three or more orders of magnitude greater affinity than $\mathrm{Fe}^{2+}$ or because the effect of these metals on PHD's is due to a mechanism other than direct competition for the iron site. While some divalent metals may inhibit PHD's in vitro, other metals may not inhibit PHD's in cells due to differential availability and storage. Although Figure 5 shows that $\mathrm{Cu}^{2+}$ and $\mathrm{Cd}^{2+}$ can also bind tightly to imids and they also inhibit PHD in vitro, these metals do not lead to a significant HIF1 alpha stabilization comparable to $\mathrm{Ni}^{2+}$ in A549 cells [60] (data not shown). However, copper has been shown to stabilize HIF- $1 \alpha$ in a human hepatoma cell line [60]. It is likely that the cellular metabolism with these metals differs from those operative with $\mathrm{Ni}^{2+}$ where as for example metallothionein will bind $\mathrm{Cd}^{2+}$ and $\mathrm{Cu}^{2+}$ but not $\mathrm{Ni}^{2+}[61,62]$. Exposure of cells to soluble nickel may yield more metal ion that is available to react with enzymes such as the PHD's, when compared to other metals. Further support for our model is derived from the fact that $\mathrm{Mg}^{2+}, \mathrm{Mn}^{2+}$, and $\mathrm{Ca}^{2+}$, which all have lower binding affinities to two imids when compared to iron, were either unable to efficiently inhibit PHD's in vitro or substantially induce HIF-1 $\alpha$ in A549 cells [63] (data not shown). It is prudent to use caution when studying metals in determining the available metal ion concentration in the reaction. Many investigators carry out in vitro prolyl hydroxylase assays with high concentration of reagents such as bovine serum albumin and DTT, which will actively sequester metal ions and render them unavailable to react with HIF-PHD. Therefore, the concentrations of metals that are needed to inactivate PHD's may be lower than actually added.

In summary, we provide evidence that exposure of A549 cells to nickel can lead to a prolonged activation and stabilization of HIF- $1 \alpha$ resulting from the inhibition of PHD enzymes. We also show that the inhibition of PHD's by nickel is at least partially due to a direct effect of nickel on the enzyme because nickel inhibits PHD2 in vitro and can bind two imid ligands (the functional group of histidine to which $\mathrm{Fe}^{2+}$ is bound) much tighter than $\mathrm{Fe}^{2+}$. The depletion of iron and oxidation of ascorbic acid may also be factors in the inhibition of PHD's in cells, though whether these events are necessary for nickel to directly affect the PHD enzymes is still unclear. Studying the mechanisms by which nickel stabilizes HIF- $1 \alpha$ may lead to a greater understanding of its regulation and therefore improve the treatment of both cancer and ischemic diseases. The effect of nickel on other iron-dependent enzymes should be the subject of future investigation.

\section{ACKNOWLEDGMENTS}

We thank Thomas Kluz for expert technical assistance. This work was supported by grant numbers 
ES00260, ES10344, and T32-ES07324 from the National Institute of Environmental Health Sciences, CA16087 from the National Cancer Institute and FP-91641801-0 from the Environmental Protection Agency.

\section{REFERENCES}

1. Wang GL, Jiang BH, Rue EA, Semenza GL. Hypoxia-inducible factor 1 is a basic-helix-loop-helix-PAS heterodimer regulated by cellular $\mathrm{O}_{2}$ tension. Proc Natl Acad Sci USA 1995; 92:5510-5514.

2. Pugh CW, Ratcliffe PJ. Regulation of angiogenesis by hypoxia: Role of the HIF system. Nat Med 2003;9:677-684.

3. Semenza GL. HIF-1 and human disease: One highly involved factor. Genes Dev 1983:14:1983-1991.

4. Semenza GL. Hypoxia-inducible factor 1: Oxygen homeostasis and disease pathophysiology. Trends Mol Med 2001; 7:345-350

5. Semenza GL. Targeting HIF-1 for cancer therapy. Nat Rev Cancer 2003;3:721-732.

6. Aalinkeel R, Nair MP, Sufrin $G$, et al. Gene expression of angiogenic factors correlates with metastatic potential of prostate cancer cells. Cancer Res 2004;64:53115321.

7. Dachs GU, Tozer GM. Hypoxia modulated gene expression: Angiogenesis, metastasis and therapeutic exploitation. Eur J Cancer 2000:36:1649-1660.

8. Hopfl G, Ogunshola O, Gassmann M. HIFs and tumorscauses and consequences. Am J Physiol Regul Integr Comp Physiol 2004:286:R608-R623.

9. Paul SA, Simons JW, Mabjeesh NJ. HIF at the crossroads between ischemia and carcinogenesis. J Cell Physiol 2004; 200:20-30.

10. Brown JM. Tumor microenvironment and the response to anticancer therapy. Cancer Biol Ther 2002;1:453-458.

11. Semenza GL. Hypoxia, clonal selection, and the role of HIF-1 in tumor progression. Crit Rev Biochem Mol Biol 2000; 35:71-103.

12. Carmeliet $P$, Dor $Y$, Herbert JM, et al. Role of HIF-1alpha in hypoxia-mediated apoptosis, cell proliferation and tumour angiogenesis. [erratum appears in Nature 1998 Oct 1; 395(6701):525 Note: Keshet E [corrected to Keshert E]]. Nature 1998;394:485-490

13. Kung AL, Wang S, KIco JM, Kaelin WG, Livingston DM. Suppression of tumor growth through disruption of hypoxiainducible transcription. Nat Med 2000;6:1335-1340.

14. Epstein AC, Gleadle JM, MCNeill LA, et al. C. elegans EGL-9 and mammalian homologs define a family of dioxygenases that regulate HIF by prolyl hydroxylation. Cell 2001;107: 43-54.

15. Jaakkola P, Mole DR, Tian YM, et al. Targeting of HIF-alpha to the von Hippel-Lindau ubiquitylation complex by $\mathrm{O}_{2}-$ regulated prolyl hydroxylation. Science 2001;292:468472

16. Bruick RK. Oxygen sensing in the hypoxic response pathway: Regulation of the hypoxia-inducible transcription factor. Genes Dev 2003:17:2614-2623.

17. Biedermann KA, Landolph JR. Induction of anchorage independence in human diploid foreskin fibroblasts by carcinogenic metal salts. Cancer Res 1987:47:3815-3823.

18. Conway K, Costa M. Nonrandom chromosomal alterations in nickel-transformed Chinese hamster embryo cells. Cancer Res 1989:49:6032-6038.

19. Doll R. Cancer of the nose and lung in nickel workers. $\mathrm{Br} \mathrm{J}$ Ind Med 1958;15:217-223

20. Grimsrud TK, Berge SR, Haldorsen T, Andersen A. Exposure to different forms of nickel and risk of lung cancer. Am J Epidemiol 2002;156:1123-1132.
21. Grimsrud TK, Berge SR, Martinsen Jl, Andersen A. Lung cancer incidence among Norwegian nickel-refinery workers 1953-2000. J Environmen Monit 2003:5:190-197.

22. International Agency for Research on Cancer I. Monographs on the evaluation of carcinogenic risks to humans: Chromium nickel and welding. Lyon, France: IARC; Vol. 49. 1990.

23. Lin X, Dowjat WK, Costa M. Nickel-induced transformation of human cells causes loss of the phosphorylation of the retinoblastoma protein. Cancer Res 1994:54:2751-2754.

24. Maenza RM, Pradhan AM, Sunderman FW, Jr. Rapid induction of sarcomas in rats by combination of nickel sulfide and 3,4-benzpyrene. Cancer Res 1971;31:2067-2071.

25. MCEwan JC. Cytological monitoring of nickel sinter plant workers. Ann N Y Acad Sci 1976;271:365-369.

26. Chen $H$, Davidson $T$, Singleton $S$, Garrick MD, Costa M Nickel decreases cellular iron level and converts cytosolic aconitase to iron-regulatory protein 1 in A549 cells. Toxicol Appl Pharmacol 2005:206:275-287.

27. Davidson T, Salnikow K, Costa M. Hypoxia inducible factor- 1 alpha-independent suppression of aryl hydrocarbon receptor-regulated genes by nickel. Mol Pharmacol 2003. 64:1485-1493.

28. Salnikow K, Davidson T, Zhang Q, Chen LC, Su W, Costa M The involvement of hypoxia-inducible transcription factor-1 dependent pathway in nickel carcinogenesis. Cancer Res 2003;63:3524-3530.

29. Li J, Davidson G, Huang $Y$, et al. Nickel compounds act through phosphatidylinositol-3-kinase/Akt-dependent p70(S6k)-independent pathway to induce hypoxia inducible factor transactivation and Cap43 expression in mouse epidermal Cl41 cells. Cancer Res 2004;64:94-101.

30. Salnikow K, Donald SP, Bruick RK, Zhitkovich A, Phang JM Kasprzak KS. Depletion of intracellular ascorbate by the carcinogenic metals nickel and cobalt results in the induction of hypoxic stress. J Biol Chem 2004;279:40337-40344.

31. D'Angelo G, Duplan E, Boyer N, Vigne P, Frelin C. Hypoxia upregulates prolyl hydroxylase activity: A feedback mechanism that limits HIF-1 responses during reoxygenation. J Biol Chem 2003:278:38183-38187.

32. Rothenberger S, Mullner EW, Kuhn LC. The mRNA-binding protein which controls ferritin and transferrin receptor expression is conserved during evolution. Nucleic Acids Res 1990;18:1175-1179.

33. Oehme F, Jonghaus W, Narouz-Ott L, Huetter J, Flamme I. A nonradioactive 96-well plate assay for the detection of hypoxia-inducible factor prolyl hydroxylase activity. Anal Biochem 2004;330:74-80

34. Martell AE, Smith RM, Motekaitis RJ. NIST critically selected stability constants of metal complexes. NIST standard reference database 46 Version 6.0. Gaithersburg, MD: US Dept of Commerce National Institute of Standards Technology; 2001.

35. Davidson T, Chen H, Garrick MD, D'Angelo G, Costa M Soluble nickel interferes with iron homeostasis. Mol Cell Biochem 2005;279:157-162

36. Grimsrud TK, Berge SR, Haldorsen T, Andersen A. Can lung cancer risk among nickel refinery workers be explained by occupational exposures other than nickel? Epidemiology $2005 ; 16: 146-154$

37. Costa M. Molecular mechanisms of nickel carcinogenesis. Ann Annu Rev Pharmacol Toxicol 1991:31:321-337.

38. Costa M. Model for the epigenetic mechanism of action of nongenotoxic carcinogens. Am J Clin Nutr 1995;61:666S6695

39. Salnikow K, Costa M. Epigenetic mechanisms of nickel carcinogenesis. J Environ Pathol Toxicol Oncol 2000;19. 307-318.

40. Kasprzak KS, Sunderman FW, Jr., Salnikow K. Nicke carcinogenesis. Mutat Res 2003:533:67-97.

41. Maxwell PH, Ratcliffe PJ. Oxygen sensors and angiogenesis. Semin Cell Dev Biol 2002;13:29-37. 
42. Erez N, Milyavsky M, Eilam R, Shats I, Goldfinger N, Rotter V. Expression of prolyl-hydroxylase-1 (PHD1/EGLN2) suppresses hypoxia inducible factor-1alpha activation and inhibits tumor growth. Cancer Res 2003;63:8777-8783.

43. Salnikow K, An WG, Melillo G, Blagosklonny MV, Costa M. Nickel-induced transformation shifts the balance between HIF-1 and p53 transcription factors. Carcinogenesis 1999; 20:1819-1823.

44. Salnikow K, Davidson T, Costa M. The role of hypoxiainducible signaling pathway in nickel carcinogenesis. Environ Health Perspect 2002;110:831-834.

45. Gao N, Jiang BH, Leonard SS, et al. p38 Signaling-mediated hypoxia-inducible factor 1 alpha and vascular endothelial growth factor induction by $\mathrm{Cr}(\mathrm{VI})$ in DU145 human prostate carcinoma cells. J Biol Chem 2002;277:45041-45048

46. Majamaa K, Kuutti-Savolainen ER, Tuderman L, Kivirikko KI. Turnover of prolyl hydroxylase tetramers and the monomersize protein in chick-embryo cartilaginous bone and lung in vivo. Biochem J 1979;178:313-322.

47. Knowles HJ, Raval RR, Harris AL, Ratcliffe PJ. Effect of ascorbate on the activity of hypoxia-inducible factor in cancer cells. Cancer Res 2003;63:1764-1768.

48. Bridges KR, Hoffman KE. The effects of ascorbic acid on the intracellular metabolism of iron and ferritin. J Biol Chem 1986;261:14273-14277.

49. Kivirikko KI, Myllyharju J. Prolyl 4-hydroxylases and their protein disulfide isomerase subunit. Matrix Biol 1998;16: 357-368.

50. Kivirikko Kl, Pihlajaniemi T. Collagen hydroxylases and the protein disulfide isomerase subunit of prolyl 4-hydroxylases. Adv Enzymol Relat Areas Mol Biol 1998;72:325-398.

51. Rapaka RS, Sorensen KR, Lee SD, Bhatnagar RS. Inhibition of hydroxyproline synthesis by palladium ions. Biochim Biophys Acta 1976;429:63-71.

52. Tuderman L, Myllyla R, Kivirikko KI. Mechanism of the prolyl hydroxylase reaction 1. Role of co-substrates. Eur J Biochem 1977;80:341-348.
53. Batie CJ, Ballou DP. Phthalate dioxygenase. Methods Enzymol 1990;188:61-70.

54. Batie CJ, LaHaie E, Ballou DP. Purification and characterization of phthalate oxygenase and phthalate oxygenase reductase from Pseudomonas cepacia. J Biol Chem 1987; 262:1510-1518.

55. Ming LJ, Que L, Jr., Kriauciunas A, Frolik CA, Chen VJ. NMR studies of the active site of isopenicillin $\mathrm{N}$ synthase, a non-heme iron(II) enzyme. Biochemistry 1991;30:1165311659.

56. Schofield CJ, Ratcliffe PJ. Oxygen sensing by HIF hydroxylases. Nat Rev Mol Cell Biol 2004;5:343-354.

57. Elkins JM, Hewitson KS, McNeill LA, et al. Structure of factorinhibiting hypoxia-inducible factor (HIF) reveals mechanism of oxidative modification of HIF-1 alpha. J Biol Chem 2003;278:1802-1806.

58. Maxwell P, Salnikow K. HIF-1: An oxygen and metal responsive transcription factor. Cancer Biol Ther 2004; 3:29-35.

59. Yuan Y, Hilliard G, Ferguson T, Millhorn DE. Cobalt inhibits the interaction between hypoxia-inducible factor-alpha and von Hippel-Lindau protein by direct binding to hypoxiainducible factor-alpha. J Biol Chem 2003;278:1591115916

60. Martin F, Linden T, Katschinski DM, et al. Copper-dependent activation of hypoxia-inducible factor (HIF)-1: Implications for ceruloplasmin regulation. Blood 2005;105:4613-4619.

61. Kagi JH, Kojima Y. Chemistry and biochemistry of metallothionein. Experientia Supplementum 1987;52:25-61.

62. Nath R, Kambadur R, Gulati S, Paliwal VK, Sharma M. Molecular aspects, physiological function, and clinical significance of metallothioneins. Crit Rev Food Sci Nutr 1988;27:41-85.

63. Hirsila M, Koivunen P, Xu L, Seeley T, Kivirikko KI, Myllyharju J. Effect of desferrioxamine and metals on the hydroxylases in the oxygen sensing pathway. FASEB J 2005;19:13081310. 